\title{
НЕЙРОМЕРЕЖЕВИЙ МЕТОД КЕРУВАННЯ ДЛЯ ТЕРМОЕЛЕКТРИЧНОГО ПЕРЕТВОРЮВАЧА 3 КЕРОВАНИМ ПРОФІЛЕМ ТЕМПЕРАТУРНОГО ПОЛЯ
}

\begin{abstract}
Анотація: В статі запропоновано нейромережевий метод підтримання заданого профілю температурного поля вздовж головної термопари (ГТП) термоелектричного перетворювача з керованим профілем температурного поля (ТЕП з КПТП).

Ключові слова: Термопара, вимірювання температури, керування профілем температурного поля, нейронні мережі.
\end{abstract}

\section{Вступ}

Термоелектричні перетворювачі е найбільш поширеними термометрами при вимірюванні середніх та високих температур [1]. Однак їх похибки є доволі значними. Через те, що їх похибки зазвичай домінують у вимірювальному каналі [2-5], то похибки їх чутливих елементів - термопар - є основним джерелом похибки вимірювання температури.

Однією із складових похибок термопар е похибка від набутої в процесі тривалої експлуатації неоднорідності їх термоелектродів. В процесі експлуатації, під дією високих температур і часу, змінюеться хімічний склад термоелектродів (окислення, міграція) і їх кристалічний стан, причому інтенсивність змін сильно залежить від температури, при якій дана ділянка перебувала під час експлуатації [6]. В результаті накопичення цих змін питома е.р.с. різних ділянок термоелектродів стає неоднаковою, тобто сумарна термо-е.р.с. термопари стає залежною не тільки від різниці температур робочого злюту та злюту порівняння, a і від розподілу температурного поля вздовж термоелектродів. Згідно [7] термоелектрична неоднорідність електродів термопар є найбільш небезпечним джерелом похибки термоелектричних перетворювачів, а в [8] стверджуеться, що похибки термопар не можна коригувати. Однак останні дослідження похибки від набутої неоднорідності електродів термопар [9-11] показали передчасність такого висновку.

Запропонований у $[12,13]$ термоелектричний перетворювач з керованим профілем температурного поля (ТЕП з КПТП) завдяки додатковим підсистемам керування температурним полем створює свій власний профріль температурного поля, в якому неоднорідність термоелектродів не може себе проявити.

Конструктивна схема запропонованого ТЕП з КПТП представлена на рис. 1. Вона містить головну термопару ТПГ, що вимірюе температуру об'єкта, додаткові термопари ТП1. . . ТПn, які контролюють профріль температурного поля вздовж електродів головної термопари, та нагрівачі

(c) О.В. Кочан , 2012 
H1...Нn, які формують власний профіль температурного поля ТЕП з КПТП. Така конструктивна схема дає змогу забезпечити для ТПГ власний, сталий профіль температурного поля вздовж їі електродів, незалежний від профілів печі для метрологічної перевірки ТЕП з КПТП та об'єкта вимірювання температури, а також змін цих профрілів в процесі експлуатації. Тому набута в процесі тривалої експлуатації неоднорідність термоелектродів ТПГ не може себе проявити.
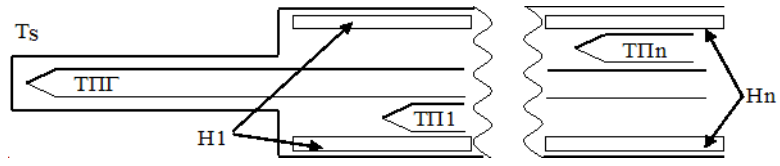

Рис. 1 - Конструктивна схема ТЕП з КПТП.

Однак в такому ТЕП проблемою е керування профрілем температурного поля. 3 точки зору теорії регулювання ТЕП з КПТП представляе собою багатозонний об'єкт регулювання з відносно тісним зв'язком між окремими зонами. Такі об'єкти з точки зору керування є складними [14]. Це пов'язано з великою схильністю таких об'єктів регулювання до самозбудження через значний вплив змін потужності одного нагрівача на температуру інших зон (тісний зв'язок між окремими зонами). Найбільш повно методи регулювання температури багатозонних об'єктів розглянуті в $[14,15]$. Але розглянуті та запропоновані в [15] методи регулювання мають дуже велику обчислювальну складність, при їх реалізації для всього двохзонного об'єкта використано персональний комп'ютер та спеціалізований пакет прикладних програм Матлаб [16]. Таке рішення $\mathrm{e}$ економічно надлишковим.

Метою статті є створення методу формування приростів потужності нагрівачів зон стабілізації профрілю температурного поля багатозонного об’екта (зокрема, головної термопари ТЕП з КПТП), який не мав би схильності до самозбудження, мав би відносно малу обчислювальну складність (на рівні $[10,17])$ при значно вищій якості керування (тобто меншій кількості ітерацій для встановлення заданого профілю температурного поля порівняно з $[10,17])$.

\section{1. Нейромережевий метод керування}

В $[10,17]$ запропоновано простий метод регулювання, придатний для керування профілем температурного поля ТЕП з КПТП, який грунтуеться на двох припущеннях:

1. Залежності приростів температури від приростів потужності нагрівачів зон є лінійними.

2. При обчисленні приростів потужності, необхідних для бажаної зміни температури окремих зон з врахуванням взаемного впливу всіх зон, сумують не прирости теплових потоків, а прирости температури. 
Прийняті припущення суперечать основам термодинаміки [18], але, при невеликих змінах температури кожної зони $\Delta T_{i}$ TЕП з КПТП та ітераційному процесі регулювання, ці припущення дають змогу забезпечити відхилення температури зон ТЕП з КПТП від заданої не більше 1 $-2^{\circ} \mathrm{C}$.

При цьому, завдяки прийнятим припущенням, можна записати систему лінійних рівнянь, які визначають приріст температури кожної зони $\Delta T_{i}$ як сумарну дію приростів потужності $\Delta P_{i}$ окремих нагрівачів

$$
\left\{\begin{array}{c}
\Delta T_{0}=k_{00} \times \Delta P_{0}+k_{01} \times \Delta P_{1}+\ldots+k_{0(K-1)} \times \Delta P_{(K-1)} \\
\Delta T_{1}=k_{10} \times \Delta P_{0}+k_{11} \times \Delta P_{1}+\ldots+k_{1(K-1)} \times \Delta P_{(K-1)} \\
\ldots \\
\Delta T_{K-1}=k_{(K-1) 0} \times \Delta P_{0}+k_{(K-1) 1} \times \Delta P_{1}+\ldots+k_{(K-1)(K-1)} \times \Delta P_{(K-1)}
\end{array}\right.
$$

де $k_{00} \ldots k_{(K-1)(K-1)}$ - коефіціенти лінеаризованої моделі ТЕП з КПТП, що визначаються експериментально.

Рішення системи рівнянь (1) дає змогу обчислити необхідні прирости потужності $\Delta P_{i}$ нагрівачів Н1...Нn для отриманих в результаті вимірювання відхилень $\Delta T_{i}$ температур зон від заданих.

Хоча система рівнянь (1) лише наближено описуе теплові процеси, що протікають в ТЕП з КПТП, однак вона дозволяе приблизно оцінити необхідні прирости потужності $\Delta P_{i}$, щоби в процесі ітераційного наближення забезпечити наближення профілю температурного поля вздовж електродів головної термопари ТЕП з КПТП до заданого. А похибка керування профрілем температурного поля викликає лише невиключену похибку від набутої термоелектричної неоднорідності головної термопари, тобто похибка керування щодо до вимірюваної головною термопарою температури об'єкта є величиною другого порядку малості. Для уникнення самозбудження введено затримку наступної керуючої дії на час, доки не закінчиться перехідний процес від попередньої. Тобто регулятор температури має фрактично розімкнуту структуру і не збуджуеться.

Однак, за рахунок значного спрощення теплових процесів через прийняті припущення, метод має також недоліки - по-перше, обчислені прирости потужності $\Delta P$ мають відносно значну похибку, тому потрібна відносно велика кількість ітерацій для встановлення заданого профілю температурного поля головної термопари ТЕП з КПТП, по-друге, компенсація значних змін зовнішнього по відношенню до ТЕП з КПТП температурного поля вимагає значних змін потужності $\Delta P$, що збільшуе (підсилює) вплив їх похибки, пов'язаної з спрощенням теплових процесів, а це знову веде до збільшення кількості ітерацій для встановлення заданого профілю температурного поля головної термопари ТЕП з КПТП. Таким чином, існують межі швидкості та амплітуди змін профрілю температурного поля, при перевищенні яких теплові перехідні процеси не будуть закінчуватися, обчислені згідно (1) прирости потужності будуть навпаки "розхитувати" профіль температурного поля вздовж електродів головної термопари, що приведе до різкого збільшення впли- 
ву похибки від набутої неоднорідності на результат вимірювання температури.

Основною причиною недоліків відомого методу є лінійний характер системи рівнянь (1). Однак перехід до системи нелінійних рівнянь настільки збільшує обчислювальну складність методу, що їі рішення в реальному часі стає простим мікроконтролерам не під силу. Як відомо [19], при керуванні нелінійними об’єктами хороші результати показують нейронні мережі. За обчислювальною складністю нейронні мережі дуже вимогливі під час навчання і вимагають в $\approx 10^{4}$ разів менше обчислювальних ресурсів при використанні вже навчених нейронних мереж [20]. Тому при умові навчання нейронної мережі на верхньому ієрархічному рівні системи (згідно [20]) нейромережеві методи можуть бути застосовані в системах на базі мікроконтролерів. Однак більшість розглянутих у [19] методів нейромережевого керування вимагають для навчання достатньо точних математичних моделей об'єкта керування. Для ТЕП з КПТП, через наявність багатьох зон нагріву та значний тепловий зв'язок між ними, ідентифікація параметрів математичної моделі є дуже складною задачею, яка вимагає великого об'єму експериментальних досліджень [14]. Крім того, така ідентифікація мусить бути виконана на об’єкті вимірювання температури через вплив параметрів об'єкта на параметри моделі ТЕП з КПТП.

Пропонований метод полягає у тому, що, по-перше, на нейронну мережу подають не тільки відхилення температури всіх зон від заданої (як у звичайному та нейромережевому регуляторах), а і самі значення температури всіх зон (що дає змогу нейронній мережі врахувати нелінійні властивості об’єкта регулювання). По-друге, для навчання нейронної мережі не створюють спеціальну модель (яка має свої похибки), а проводять навчання безпосередньо на об'єкті (тоді модель та її похибки просто відсутні). Розглянемо реалізацію пропонованого методу керування профрілем температурного поля ТЕП з КПТП детальніше.

\section{2. Структура нейромережевого регулятора профілю температурного поля}

Нейромережевий регулятор температури ТЕП з КПТП (рис. 2) складається з нагрівачів Н всіх зон ТЕП з КПТП і давачів Д температури (додаткових термопар) цих зон, що підключені до входів багатоканальної вимірювальної підсистеми БВП, виходи якої (результати вимірювання температури всіх зон) поступають на входи блоків віднімання БВ та нейронної мережі НМ. Виходи нейронної мережі НМ поступають на входи блоків керування БК потужністю, виходи яких підключені до нагрівачів Н відповідних зон. Температури всіх зон (нагрівачів Н) задаються блоком задання температури Б3 ${ }^{\circ}$, виходи якого підключені до входів блоку віднімання БВ. Отримані на виході БВ відхилення температури окремих зон поступають на входи нейронної мережі НМ. У склад багатоканальної вимірювальної підсистеми БВП входять комутатор сигналів додаткових термопар КМ, аналого-цифровий перетворювач АЦП, мікро- 
контролер обробки поточних результатів аналого-цифрового перетворення МК та інтерфейс ІФ. Для синхронізації роботи блоків керування БК, які доцільно виконати на базі широтно-імпульсних регуляторів, а також формування відповідної затримки між змінами керуючої дії (потужності, яка виділяеться кожним нагрівачем Н) для уникнення небезпеки самозбудження, в схему введено також Таймер. Сам ТЕП з КПТП розміщений в ПЕЧІ, температура якої встановлюється своїм Регулятором температури печі згідно блоку задання температури БЗ $\mathrm{t}^{\circ}$ печі.

Пропонований нейромережевий регулятор температури працюе циклічно. На початку кожного циклу БВП вимірюе поточну температуру кожної зони ТЕП з КПТП. Результати вимірювання поступають на входи блока віднімання БВ. Відхилення поточної температури кожної зони ТЕП з КПТП (різниця між поточною температурою кожної зони та заданим БЗ $\mathrm{t}^{\circ}$ значенням температури цієї зони) поступають на входи нейронної мережі НМ. На додаткові входи НМ поступають значення поточної температури кожної зони. Нейронна мережа НМ обчислюе необхідні прирости (або зменшення) потужності нагрівачів кожної зони, а блоки керування БК реалізують ці зміни. Фактично змінюеться шпарність імпульсів, які формують блоки керування БК.

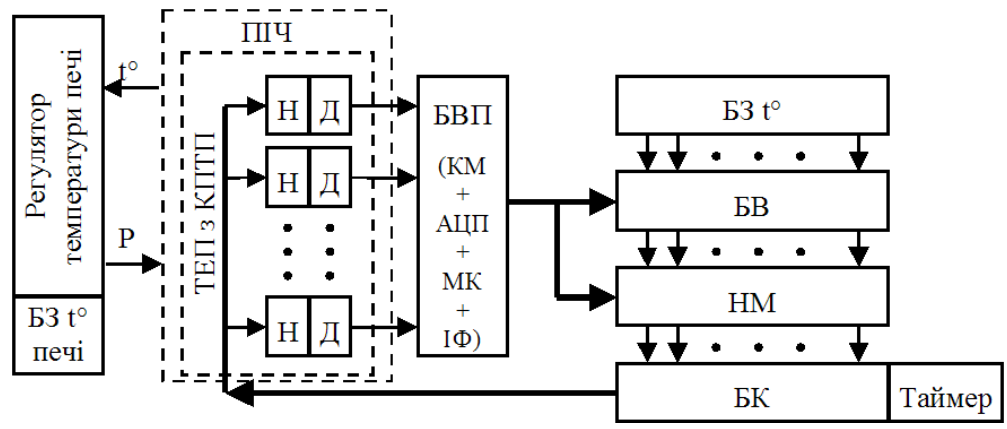

Рис. 2 - Структурна схема нейромережевого регулятора в режимі підтримання профілю температурного поля

Відповідно до структури нейромережевого регулятора, як нейронну мережу НМ, що формуе керуючі дії для блоків керування БК можна використати відомий тришаровий персептрон [21]. Він має мати входів вдвічі більше, ніж кількість зон ТЕП з КПТП, а виходів - стільки ж, скільки зон. Структура цієї нейронної мережі представлена на рис. 3.

Завданням нейронної мережі НM е формування керуючих впливів таким чином, щоби отримати мінімальний час переходу поточного профрілю температурного поля вздовж електродів головної термопари ТЕП з КПТП до заданого профілю. Для цього вона має бути відповідно навчена. Як вже вказувалося раніше, навчання цієї нейронної мережі на моделі вимагає побудови моделі, що відповідає умовам експлуатації ТЕП з КПТП на об'єкті вимірювання температури. Побудова такої моделі до- 


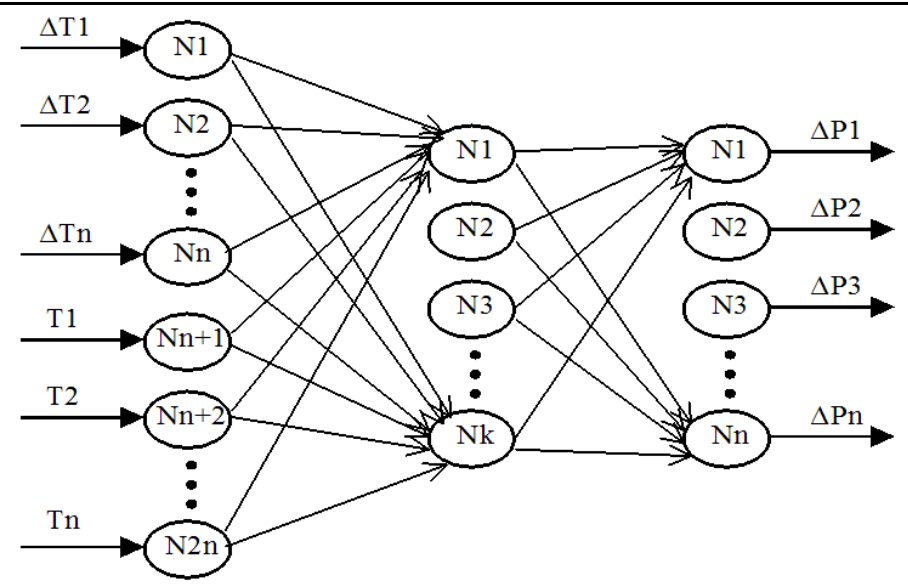

Рис. 3 - Структура нейронної мережі НМ, що використовується для формування керуючої дії

статньої точності дуже трудомістка, тому запропоновано метод навчання НM безпосередньо на місці експлуатації.

\section{3. Метод навчання нейронної мережі}

Для навчання нейронної мережі НМ необхідно створити навчальну вибірку [21], в якій заданим значенням відхилень температури кожної зони ТЕП з КПТП (які повинні поступати на вхід нейронної мережі) будуть відповідати значення приростів потужності, адекватні для приведення до заданого профілю температурного поля для цілого ТЕП з КПТП (тому, що зони мають значний тепловий зв'язок). Такі значення приростів потужності апріорі невідомі, їх можна визначити обчислювальним шляхом, побудувавши модель, однак, як було вказано, побудова моделі достатньої точності дуже трудомістка. Тому запропоновано навчання НM безпосередньо на місці експлуатації шляхом ії̈ зворотного ввімкнення. Для цього структуру нейромережевого регулятора необхідно змінити так, як це показано на рис. 4 . Під час навчання блок задання потужності БЗП випадковим чином задае прирости (як додатні, так і від’ємні) потужності нагрівачів Н (кожної зони), які реалізують блоки керування БК. Після закінчення перехідного процесу багатоканальна вимірювальна підсистема БВП визначить відповідні реальні температури кожної зони і подасть їх на блок віднімання БВ і нейронну мережу НМ. Блок задання температури БЗ ${ }^{\circ}$ в момент задання приростів потужності нагрівачів Н отримуе від блока задання потужності БЗП команду на запам'ятовування значення температури, яке було перед зміною потужності нагрівачів Н, яке він подає на блок віднімання БВ. Таким чином, на входах нейронної мережі маємо значення температур всіх зон та їі змін під дією заданих приростів потужності, тобто ми маємо набір 
даних, потрібний для формування одного навчального вектора для нейронної мережі НМ. Обчислення потрібних змін коефіцієнтів передачі та зміщень нейронів мережі НМ виконуе блок навчання нейронної мережі БH.

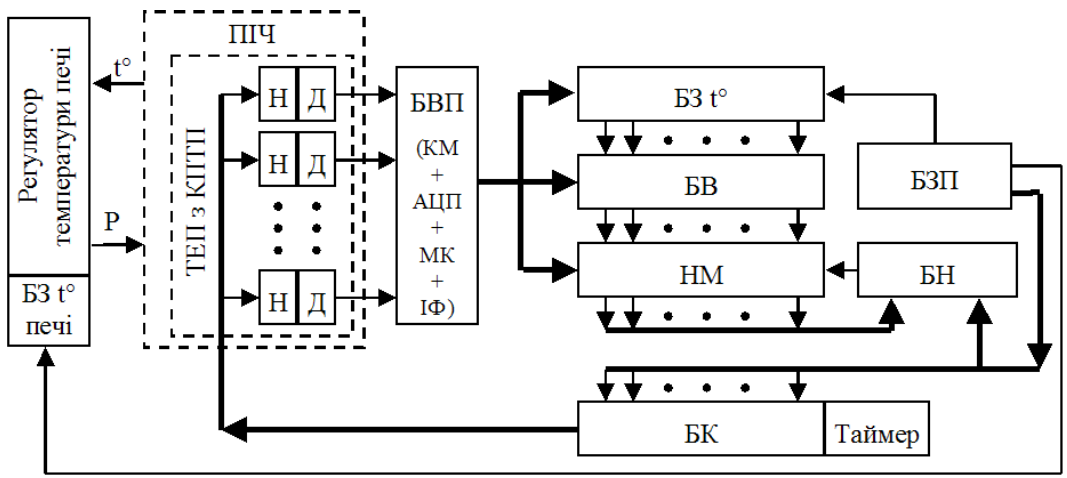

Рис. 4 - Структурна схема пристрою вимірювання температури в режимі навчання нейронної мережі

Для того, щоби врахувати при навчанні нейронної мережі зміну теплових параметрів ТЕП з КПТП слід не тільки змінювати прирости потужності всіх нагрівачів Н1... Нn, а також змінювати температуру в печі, де розміщений ТЕП з КПТП. Для цього на структурній схемі рис. 4 передбачено зв'язок між блоком задання потужності БЗП та блоком задання температури БЗ $\mathrm{t}^{\circ}$ печі. Порядок формування навчальних вибірок для навчання нейронної мережі ілюструє рис. 5 , де по осі абсцис відкладений час $\tau$, а по осі ординат - температуру одніеї із зон ТЕП з КПТП, наближеної до робочого злюту головної термопари. На рис. 5 видно базові температури $\mathrm{t}^{\circ} 1, \mathrm{t}^{\circ} 2, \mathrm{t}^{\circ} 3$, що визначаються змінами температури печі під дією блоком задання температури БЗ ${ }^{\circ}$ печі, та зміни профілю температурного поля $\Delta \mathrm{t}^{\circ} 1, \Delta \mathrm{t}^{\circ} 2, \Delta \mathrm{t}^{\circ} 3$, що визначаються блоком задання потужності БЗП.

Температури інших зон щодо базової температури відповідають профрілю температурного поля печі, а конкретне значення приростів температури визначаеться приростами потужності, заданими БЗП.

Для формування достатньої для навчання тришарового персептрона навчальної вибірки [21] описаний процес слід повторити для отримання $20-30$ векторів, що відповідають реальним змінам температури нагрівачів під дією блоків керування БК і регулятора температури печі. Після цього процес навчання можна продовжити на цій навчальній вибірці без зміни потужності нагрівачів ТЕП з КПТП, що значно прискорить процес навчання. Навчання НМ закінчуеться, коли формовані нею необхідні прирости потужності нагрівачів будь якої зони будуть задовольняти умову 


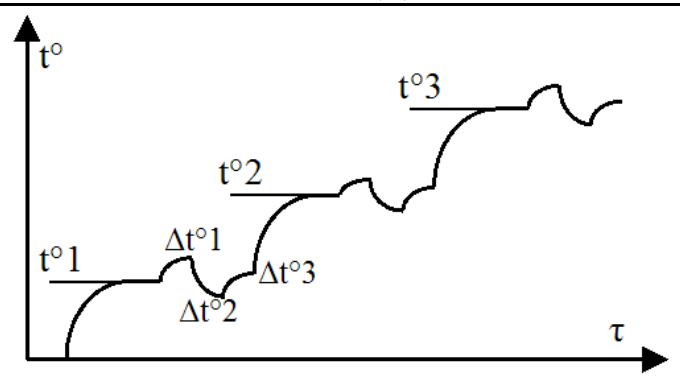

Рис. 5 - Зміни температури одніеї із зон ТЕП з КПТП під час формування навчальної вибірки

$$
\left|\Delta P_{i}-\Delta P_{i}^{N N}\right| \leqslant \varepsilon
$$

де $\Delta P_{i}$ - заданий приріст потужності $i$-тої зони; $\Delta P_{i}^{N N}$ - обчислений нейронною мережею НМ приріст потужності $i$-тої зони; $\varepsilon$ - допустима похибка оцінки потрібної зміни потужності, яка може бути приблизно оцінена за фрормулою

$$
\varepsilon=\Delta T_{i}^{D O P} \frac{\Delta P_{i}}{\Delta T_{i}},
$$

де $\Delta T_{i}^{D O P}$ - допустиме відхилення профілю температурного поля для $i$-тої зони; $\Delta T_{i}$ - значення зміни температури для $i$-тої зони, отримане при дії приросту $\Delta P_{i}$ потужності $i$-тої зони.

Залежності (2) і (3) нескладні, тому контролювати хід і закінчення процесу навчання НМ може мікроконтролер, який в майбутньому буде обчислювати значення керуючих впливів для блоків керування БК. При цьому значення допустимих відхилень профілю температурного поля $\Delta T_{i}^{D O P}$ визначаеться допустимою невиключеною похибкою від набутої в процесі тривалої експлуатації термоелектричної неоднорідності електродів головної термопари ТПГ ТЕП з КПТП (див. рис. 1). Через те, що ця невиключена похибка є по відношенню до результату вимірювання температури величиною другого порядку малості, значення $\Delta T_{i}^{D O P}$ може бути досить великим - декілька градусів [10]. Однак цикл регулювання температури ТЕП з КПТП досить тривалий, згідно оцінок [10], він перевищуе одну годину. Тому доцільно вибирати $\Delta T_{i}^{D O P}$ в межах $1-2^{\circ} \mathrm{C}$ щоби мати відповідний запас для змін профрілю температурного поля ТЕП з КПТП за рахунок проникнення профілю зовнішнього температурного поля за час циклу регулювання. Оцінити цей вплив можна за результатами досліджень, описаними в [22].

\section{Висновки}

Таким чином, процес навчання нейронної мережі відповідно до пропонованого методу не вимагає побудови математичних моделей об'єкта 
керування через суміщення процесів експериментального дослідження та навчання нейронної мережі. Через таке суміщення навчена нейронна мережа цілком адекватна саме об'єкту, а не його моделі. Запропонований метод залишається стійким через те, що перехід на змінене значення потужності нагрівачів всіх зон, яке фрормує блок керування потужністю нагрівачів, здійснюеться лише після закінчення перехідного процесу нагріву (охолодження) всіх зон (аналогічно до [10, 17]), тобто система регулювання залишається розімкнутою. Обчислювальна складність пропонованого методу не е вищою від методу запропонованого у $[10,17]$ - кількість операцій при обчисленні значення виходів нейронної мережі є приблизно еквівалентною до кількості операцій при рішенні системи лінійних рівнянь виду (1). В той же час нейронна мережа, завдяки тому, що до її додаткових входів підключено вихід багатоканальної вимірювальної підсистеми, отримуе та узагальнюе інформацію про залежність параметрів ТЕП з КПТП від саме температури окремих зон. Це дозволяе, за рахунок навчання нейронної мережі, врахувати нелінійні властивості ТЕП з КПТП як об'єкта керування. Ці нелінійні властивості викликані залежностями теплоемності та теплопровідності елементів ТЕП з КПТП від температури [23]. Метод запропонований у [10, 17] принципово не може врахувати цю нелінійність, бо система рівнянь (1) є лінійною, а перехід до рішення системи нелінійних рівнянь настільки ускладнить їі рішення, що його не можна буде реалізувати на мікроконтролері.

В той же час реалізація обчислення значення одного виходу нейронної мережі для 10 вхідних розподільчих нейронів та 10 нейронів схованого шару із сигмоїдною функцією активації на мікроконтролері AT89C52 (ціна близько 1,5 долара США) вимагає не більше 100 мс [20].

Пропонований метод керування профілем температурного поля ТЕП з КПТП забезпечуе, порівняно з $[10,17]$, значно вищу якість керування (меншу кількість ітераційних циклів, необхідних для входження в межі допуску на профріль температурного поля ТЕП з КПТП) навіть при значних змінах профрілю температурного поля. Цей метод може значно покращити експлуатаційні властивості ТЕП з КПТП, зокрема, зменшити час його реакції на зміни зовнішнього профілю температурного поля. Також пропонований метод може знайти використання при керуванні профілем температурного поля багатозонними печами, наприклад, термообробки фарфорових виробів.

\section{Література}

1. Data Acquisition Units [електронний ресурс]. - режим доступу : http://www.fluke-test.com.au/netdaq.htm.

2. Fluke and Philips Catalog. 2006.

3. Kroese B. An introduction to Neural Networks.- Amsterdam: Univercity of Amsterdam.- 1996.-120p.

4. Panel indicators. - [електронний pecypc]. - режим доступу : http://www.thermo-electra.com/en/Products/Instruments. 
5. Southworth D.J. Temperature Calibration with Isotech Block Baths / Southworth D.J. - Handbook of Isothermal Corporation Limited 1999.

6. Васильків Н.М. Підвищення точності вимірювання температури термопарами в процесі експлуатації: автореф. дис. на здобуття наук. ступеня канд. техн. наук: спец. 05.11.04 - прилади і методи вимірювання теплових величин / Н.М. Васильків. - Львів, 2010. - 19 c.

7. Васильків Н.М. Стенд дослідження термоелектричних перетворювачів з керованим профілем температурного поля /Н.М. Васильків, О.В. Кочан, В.Я. Яскілка // Вісник Тернопільського державного технічного університету. - 2009. - №1. - С. 122-130.

8. Воловик П.М. Фізика для університетів. / П.М.Воловик - Київ; Ірпінь: Перун, 2005. - 864 с.

9. Домінюк Т. І., Вплив технологічних і експлуатаційних чинників на термоелектричну неоднорідність та метрологічні характеристики термометрів : автореф. дис. на здобуття наук. ступеня канд. техн. наук: спец. 05.11.04 - прилади і методи вимірювання теплових величин / T.I. Домінюк . - Львів, 2011. - 20 с.

10. Енциклопедія термометрії / Я.Т. Луцик, Л.К. Буняк, Ю.К. Рудавський, Б.І. Стадник. - Львів: Видавництво Національного університету “Львівська політехніка”, 2003. - 428 с.

11. Кетков Ю. MATLAB 7: программирование, численные методы : Самоучитель / Ю. Кетков, А. Кетков, М. Шульц // Санкт Петербург : БХВ-Петербург, 2005. - 742 с.

12. Киренков И.И. Некоторые законы термоэлектрической неоднородности / И.И. Киренков // Исследование в области температурных измерений: Сб.тр. - Москва: ВНИИМ. - 1976. - С. 11-15.

13. Кочан О.В. Мікроконтролерний метод керування профілем температурного поля /О.В. Кочан , Р.В. Кочан // Вісник Національного університету “Львівська Політехніка”. Комп’ютерні системи та мережі. - 2008. - № 630. - С. 67-76.

14. Кочан О.В. Термоелектричний перетворювач з керованим профрілем температурного поля: автореф. дис. на здобуття наук. ступеня канд. техн. наук: спец. 05.11.04 - прилади і методи вимірювання теплових величин / О.В. Кочан . - Львів, 2011. - 20 с.

15. Кочан О.В. Термоелектричний перетворювач з керованим профрілем температурного поля / Кочан О.В. // Вісник Тернопільського Державного Технічного Університету. - 2008. - N2. - С. 102-108.

16. Кухлинг Х. Справочник по физике. / Х. Кухлинг ; Пер. с нем. - Москва: Мир, 1982. - 520 с.

17. Мирошник И.В. Согласованное управление многоканальными системами. / И.В. Мирошник Ленинград: Энергоатомиздат, 1990. $235 \mathrm{c}$. 
18. Омату Сигеру . Нейрокомпьютеры и их применение. Книга 2. Нейроуправление и его приложения / Сигеру Омату, Марзуки Халид, Рубия Юсоф; Пер с англ. Н. В. Батина - Москва: ИПРЖР 2000. - 272 c.

19. Пат. № 97464 Україна, МПК G01К 15/00. Термоелектричний перетворювач / Кочан О.В., Кочан Р.В. - заявл. 22.02.2007.

20. Перетворювачі термоелектричні. Номінальні статичні характеристики перетворення : ДСТУ 2837-94 . - [Чинний від 1986-04-01 ] - К.: Держстандарт України, 1994. - (Національний стандарт України)

21. Рогельберг Н.А. Изменения термоэлектрической силы проволок из хромеля и алюмеля при нагреве на воздухе при $800^{\circ} \mathrm{C}$ продолжительностью до 10000 ч. Том ІІІ. / Рогельберг Н.А., Пигидина Э.Н., Покровская Г.Н. и др. - Сб. Исследование сплавов для термопар. Труды института Гипроцветметобработка. - Москва: Металлургия, 1969.

22. Соболев А. В. Повышение точности регулирования температурного поля путем совершенствования алгоритма управления многозонным термическим объектом : дис. ... кандидата. техн. наук: 05.13.06 / Соболев Андрей Владимирович. - Рыбинск, 2004 - 159 с.

23. Турченко В.О. Нейромережеві методи і засоби підвищення ефективності дистрибутивних мереж збору та обробки сенсорних даних: автореф. дис. на здобуття наук. ступеня канд. техн. наук: спец. 05.13.13 “Обчислювальні машини, системи, мережі” / В.О. Турченко. - Львів, 2001. - 16 с.

Отримано 12.11.2012 p. 